\title{
ANALISIS PENGARUH KEPUTUSAN INVESTASI, KEPUTUSAN PENDANAAN DAN KEBIJAKAN DEVIDEN TERHADAP NILAI PERUSAHAAN DENGAN UKURAN PERUSAHAAN SEBAGAI VARIABEL MODERASI \\ (Studi Kasus Pada Perusahaan Manufaktur Sektor Barang Konsumsi Yang Terdaftar Di Bei Tahun 2016-2019)
}

\author{
Fifta Dian Fitiriawati \\ Emal:fifta.df@gmail.com
}

\author{
Retno Wulandari
}

Ati Retna Sari

Program Studi Akuntansi, Fakultas Ekonomika Dan Bisnis, Universitas PGRI Kanjuruhan Malang

\begin{abstract}
Abstrak
Tujuan atas penelitian ini yakni untuk menjelaskan serta menganalisis pengaruhnya keputusan investasi, keputusan pendanaan dan kebijakan deviden terhadap nilai perusahaan dengan ukuran perusahaan sebagai variabel moderasi pada perusahaan manufaktur sektor barang konsumsi di BEI tahun 2016-2019. Populasi yang digunakan pada penelitian ini ialah perusahaan manufaktur sektor barang konsumsi yang terdaftar di BEI. Sampel yang digunakna ialah 18 perusahaan dengan periode pengamatan 4 tahun yaitu 2016-2019. Metode ditentukannya sampel yakni digunakannya metode purposive sampling. Metode pengolahan data yang digunakan pada penelitian ini adalah analisis moderated regression analysis (MRA) menggunakan spss versi 22. Hasil telah memberikan simpulan yakni, keputusan investasi memengaruhi nilai perusahaan, keputusan pendanaan memengaruhi nilai perusahaan, kebijakan deviden memengaruhi nilai perusahaan, ukuran perusahaan mampu diperkuat oleh pengaruh keputusan investasi pada nilai perusahaan, ukuran perusahaan tidak mampu diperkuat pengaruhnya keputusan pendanaan pada nilai perusahaan, ukuran perusahaan tidak mampu diperkuat adanya pengaruh kebijakan deviden pada nilai perusahaan.
\end{abstract}

Kata kunci: Keputusan investasi, keputusan pendanan, kebijakan deviden, ukuran perusahaan, nilai perusahaan.

\section{Abstract}

This study aims to determine and analyze the effect of investments decisiones, funding decisions and dividend policies on firm value with company size as a moderating variable in consumer goods sector manufacturing companies listed on the IDX in 2016-2019. The population used in this study are manufacturing companies in the consumers goods sector which are listed on the IDX. The sample used is 18 companies with an observation period of 4 years, namely 2016-2019. The sampling method used in this study is purposive sampling method. The data processing method used in this study is moderated regression analysis (MRA) using SSS version 22. The results of this study indicate that investment decisions have an effect on firm value, fundling decisions haven an effect on firm value, dividend policy affects firm value, firm size able to strengthen the effect of investment 
decisions on firm value, firm size is not able's than strengthen the effect of funding decisions on firm value, firm size is not able to strengthen the effect of dividend policys on firm values.

Keywords: investment decisions, funding decisions, dividend policy, firms size, firms value

\section{PENDAHULUAN}

Terkait bisnis Indonesia telah mangalami perkembangan diikuti dengan meningkatnya perusahaan dari tahun ke tahun. Berdasarkan kenyataannya persaingan makin kuat antar emiten dan membuat perusahaan untuk melakukan berbagai pengembangan bisnis agar tetap bisa bertahan. Salah satu sektor usaha yang terdaftar di BEI ialah perusahaan manufaktur sektor barang konsumsi. Yang terdapat beberapa sub sektor yaitu sub makanan serta minuman, sub sektor kosmetik dan rumah tangga, sub sektor farmasi, sub sektor pabrik tembakau, dan sub sektor lain.

Perusahaan sektor barang konsumsi di Indonesia menurut Mirae Asset Sekuritas Indonesia pada riset yang dipublikasikannya hari Jum'at (19/10/2018), mengatakan bahwa sedang teralaminya perlambatan pada beberapa tahun terakhir. Yang disebabkan karena beberapa faktor yaitu semakin ketatnya persaingan antar perusahaan yang mengaitkan beberapa merek impor dan lokal. Kemudian menurunnya daya beli khalayak umum serta pergeseran pilihan konsumen dari barang konsumsi ke barang non konsumsi. Perlambatan pada sektor barang konsumsi yakni cerminan atas kinerja beberapa emiten yang terdaftar di (BEI), seperti PT Unilever Indonesia Tbk (UNVR) yang kinerjanya anjlok hingga 19,7\%, PT CBP Sukses Makmur Tbk (ICBP) yang sahamnya jatuh 3,57\% dan PT Kalbe Farma Tbk (KLBF) juga menurun 20,23\%. (sumber: cnbcindonesia.com diakses pada 10 Desember 2019)

Tujuan perusahaan yang dianggap paling tepat adalah memaksimalkan nilai perusahaan karena memaksimalkan nilai perusahaan itu berorientasi jangka panjang, pemaksimalan nilai emiten lebih mengutamakan arus kas dari pada laba, dan tidak melupakan tanggung jawab sosial perusahaan. Sudana (2011). Sehingga nilai perusahaan dapat digunakan untuk menganalisis kondisi dari perusahaan yang akan ditanami modal oleh investor yang dapat dilihat pada harga pasar saham, agar investor mengetahui apakah investasi yang dilakukan akan mendapatkan keuntungan seperti yang diharapkan atau tidak.

Setiap perusahaan pasti akan memaksimalkan nilai perusahaan agar dapat memakmurkan pemegang sahamnya. Hal ini berkaitan dengan fungsi dan peran manajemen keuangan. Menurut Hilal (2014), ada 3 fungsi atas manajemen keuangan yang utama, yaitu keputusan investasi, keputusan pendanaan dan keputusan deviden. Manajemen keuangan dapat di artikan sebagai pengelola dana pada beberapa investasi sesuai keefektifannya ataupun bisnis terkumpulnya dana dalam membiayai investasi atau pembelanjaan secara efektif. Jadi, ketiga fungsi manajemen keuangan tersebut menjadi hal yang penting untuk pengambilan keputusan dibidang keuangan.

Penelitian ini sesuai dengan peneliti sebelumnya dikarenakan adanya perbedaaan hasil. Terkait dengan penelitian ini, sebelumnya telah diteliti oleh Utami dan Ni Putu Ayu (2018). Tetapi pada penelitian sebelumnya belum menggunakan variabel moderasi. Maka dari itu peneliti menambahkan variabel moderasi yakni ukuran perusahaan. Dimana ukuran perusahaan bisa menggambarkan seberapa besar sebuah emiten yang bisa terlihat dari total aset, rata-rata jumlah penjualan, jumlah penjualan, dan lain-lain. Mardiyati, et al (2015). 


\section{TINJAUAN PUSTAKA}

\section{A. Nilai Perusahaan}

Nilai perusahaan bisa bermakna keadaan atas suatu emiten yang bisa dilihat dengan harga saham yang dibentuk dari jual beli saham pada pasar modal yang direfleksikan penilaian pihak luar dengan kinerja perusahaan. Harmono (2014). Nilai perusahaan didefinisikan sebagai keadaan dan kondisi dari perusahaan pada tingkat tertentu sebagai bentuk penilaian masyarakat pada perusahaan yaitu sejak perusahaan itu berdiri dan berproduksi hingga sekarang. Nilai perusahaan yang selalu bertumbuh dinilai sebagai prestasi yang baik dan sebagai tolak ukur tercapainya misi emiten dikarenakan peningkatan nilai perusahaan akan meningkatkan kesejahteraan investor. Fauziah dan Nadia Asandimitra (2018).

\section{B. Keputusan Investasi}

Keputusan investasi berkaitan dengan kebijakan manajer untuk menginvestasikan modal pada beberapa aset untuk mendapatkan laba dimasa mendatang atau kebijakan manajer keuangan bagaimana mengelola dana pada beberapa investasi yang menghasilkan keuntungan dikemudian hari. Piristina dan Khairunnisa (2019). Keputusan investasi merupakan kebijakan yang tak kalah pentingnya dari keputusan pendanaan serta kebijakan deviden. Investasi modal terkait indikator pertama dari kebijakan manajemen keuangan dikarenakan investasi yakni wujud pengalokasian modal yang nantinya mendapatkan laba. Harmono (2011).

Pada variabel keputusan investasi menggunakan signaling theory. Menurut Brigham dan Houston (2014) signaling theory yakni sebuah sinyal yang perusahaan berikan kepada investor untuk mengurangi asimetri informasi di antara perusahaan dengan investor. Informasi tersebut adalah catatan dari perusahaan dimasa lalu, saat ini ataupun dimasa yang akan datang. Kemudian terkait signal yang dimaksud ialah tindakan atau keputusan yang dilakukan oleh manajemen keuangan salah satunya adalah mengenai keputusan investasi, yang memberikan tanda yang baik tentang pertumbuhan dan perkembangan perusahaan dimasa mendatang yang bisa menaikkan harga saham sebagai penilaian dari nilai perusahaan.

\section{Keputusan Pendanaan}

Keputusan pendanaan yakni terpilihnya sumber dana yang akan digunakannya perusahaan guna mendanai investasi yang sudah terencana sesuai alternatif sumber dana yang dimiliki, jadi terperolehnya kombinasi penggunaan dana yang efisien. Sudana (2011). Keputusan perusahaan juga mengindikasikan mengenai pembiayaan aktiva perusahaan yang berkaitan dengan struktur keuangan perusahaan karena meliputi modal pribadi, hutang jangka panjang serta jangka pendek. Mardiyati, et al (2015).

Pada variabel keputusan pendanaan menggunakan pecking order theory dan trade off theory. Pecking order theory menurut Sofia dan Lena Farida (2017) berisi tentang urutan pendanaan pada perusahaan yang digunakan sebagai modal. Dimana manajer akan menetapkan urutan keputusan pendanaan yang pertama kali ialah laba ditahan, utang serta diterbitkannya saham untuk langkah terakhir. Kemudian untuk trade off theory menyatakan jika perusahaan menggunakan hutang yang besar maka akan mempunyai risiko kesulitan keuangan karena perusahaan akan membayar bunga yang besar yang umumnya tidak dapat disembunyikan oleh perusahaan. Mardiyati, et al (2015).

\section{Kebijakan Deviden}

Kebijakan deviden berkaitan mengenai keuntungan yang didapatkan emiten pada akhir periode 
yang dapat terbagikan kepada investors berupa deviden atau digunakan untuk laba ditahan untuk pembiayaan investasi dimasa mendatang. Utami dan Ni Putu Ayu (2018). Kebijakan deviden yaitu kebijakan yang menentukan berapa besar keuntungan setelah pajak yang didapatkan perusahaan akan diberikan pada bentuk deviden kepada pemegang saham. Sudana (2011).

Pada kebijakan deviden terdapat beberapa teori menurut Sudana (2011), yaitu:

1) Bird in the Hand Theory

Menurut Gordon dan Lintner penjelasan tersebut berpendapat jika pemegang saham menginginkan deviden yang besar dibandingkan dengan capital gain sebagai imbal hasil dari investasi yang sudah dikeluarkan. Pembagian deviden saat ini lebih disukai karena investor beranggapan bahwa memperoleh deviden saat ini memiliki risiko yang rendah daripada memperoleh capital gain dimasa mendatang, meskipun kedepannya capital gain dapat memberikan keuntungan yang besar daripada deviden saat ini.

2) Tax Preferences Theory

Teori ini berlawanan arah dengan harga pasar saham perusahaan. Yang artinya bahwa pembagian deviden yang tinggi maka akan menurunkan harga pasar saham perusahaan tersebut, karena pajak deviden lebih besar dibandingkan pajak capital gain yang dapat membuat pemegang saham untuk menginvestasikan keuntungannya daripada dibagikan.

\section{E. Ukuran Perusahaan}

Ukuran perusahaan yakni besar kecilnya emiten ditunjukkan maupun dapat dinilai dari total aset, beban pajak, total penjualan, jumlah laba dan lainnya. Brigham dan Houston (2010). Ukuran perusahaan juga menjelaskan besar maupun kecilnya emiten yang dijelaskan atas total aset, rata-rata total penjualan, jumlah penjualan, dan rata-rata total aset. Mardiyati, et al (2015).

Menurut Animah dan Rahmi (2010) menjelaskan bahwa ada beberapa kriteria dari ukuran perusahaan, yaitu :

1) Perusahaan Besar

Perusahaan besar yakni emiten sudah go publik di pasar modal serta mempunyai aset yang besar sekurang-kurangnya Rp. 200 milyar.

2) Perusahaan Menengah

Perusahaan menengah yakni emiten yang terdaftar di pasar modal pada papan pengembangan kedua biasanya memiliki total aset diantara 2 milyar - 200 milyar.

3) Perusahaan Kecil

Perusahaan kecil ialah emiten yang kadang belum terdaftar di bursa efek dan mempunyai aset kurang dari 2 milyar. 


\section{F. Kerangka Konseptual}

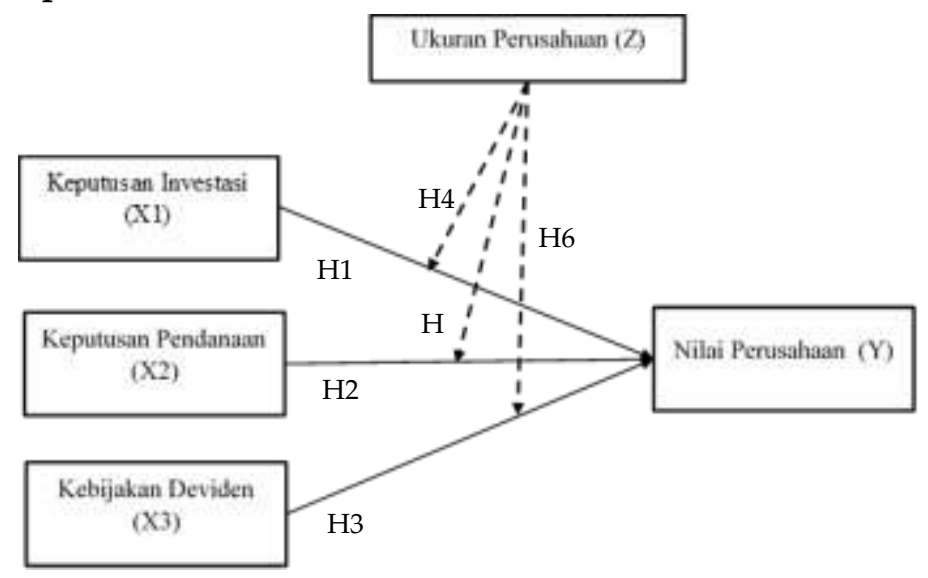

\section{Keterangan:}

\section{$\longrightarrow$ : Berpengaruh Parsial \\ $--\ldots$ - $\rightarrow$ : Berpengaruh Moderasi}

\section{Keterangan Hipotesis}

$\mathrm{H}_{1}$ : Keputusan investasi memengaruhi nilai perusahaan

$\mathrm{H}_{2}$ : Keputusan pendanaan memengaruhi nilai perusahaan

$\mathrm{H}_{3}$ : Kebijakan deviden memengaruhi terhadap nilai perusahaan

$\mathrm{H}_{4} \quad$ : Ukuran perusahaan mampu diperkuatnya pengaruh keputusan investasi pada nilai perusahaan

$\mathrm{H}_{5} \quad$ : Ukuran perusahaan mampu diperkuatnya pengaruh keputusan pendanaan pada nilai perusahaan

$\mathrm{H}_{6} \quad$ : Ukuran perusahaan mampu diperkuatnya pengaruh kebijakan deviden pada nilai perusahaan

\section{METODE}

Populasi yang dipakai merupakan perusahaan manufaktur sektor barang konsumsi yang terdaftar di BEI tahun 2016-2019. Untuk pengambilan sampel, peneliti digunakannya teknik purposive sampling. Adapun kategori terambilnya sampel yakni semua perusahaan manufaktur sektor barang konsumsi yang terdaftar di BEI periode 2016-2019, perusahaan manufaktur sektor barang konsumsi yang menerbitkan laporan keuangan (annual report) per 31 Desember pada periode 2016-2019, dan perusahaan manufaktur sektor barang konsumsi yang membayarkan deviden pada periode 2016-2019. Dari kriteria tersebut mendapatkan 18 perusahaan yang digunakan sebagai sampel penelitian. Analisis yang digunakan ialah Moderated Regression Analysis (MRA) untuk mengetahui ada tidaknya pengaruh variabel bebas yakni keputusan investasi, keputusan pendanaan serta kebijakan deviden pada variabel terikat yakni nilai perusahaan dengan ukuran perusahaan sebagai variabel moderasi. 


\section{HASIL DAN PEMBAHASAN}

\section{A. Hasil}

Dilakukannya Analisis deskriptif untuk menjelaskan angka yang diperoleh. Adapun hasil penelitian dan analisis deskriptifnya yaitu, pada variabel Y (Nilai Perusahan) yang diproksikan dengan Tobin's $Q$ dengan jumlah data $(\mathrm{N})$ sebanyak 18 dengan periode 2016-2019 memiliki nilai rata-rata tahun 2016 sebesar 3,12, pada periode 2017 sebesar 3,85, tahun 2018 sebesar 3,91 dan tahun 2019 sebesar 5,69. Untuk nilai terendah dari Tobin's Q yaitu tahun 2016 sebesar 1,03, tahun 2017 sebesar 0,90, tahun 2018 sebesar 0,83 dan tahun 2019 sebesar 0,83. Nilai terendah dari Tobin's Q ini dimiliki oleh perusahaan Chitose Internasional Tbk (CINT). Nilai tertinggi dari Tobin's Q di tahun 2016 yaitu sebesar 8,13, tahun 2017 sebesar 8,39, di tahun 2018 sebesar 9,50 dan tahun 2019 sebesar 10,68. Nilai tertinggi Tobin's Q untuk tahun 2016 dimiliki oleh perusahaan Darya-Varia Laboratoria Tbk (DVLA), untuk tahun 2017 dimiliki oleh perusahaan Ultra Jaya Milk Industry \& Tra (ULTJ), tahun 2018 dimiliki oleh perusahaan perusahaan H.M Sampoerna Tbk (HMSP) dan pada tahun 2019 dimiliki oleh perusahaan Nippon Indosari Corpindo Tbk (ROTI).

Pada variabel X1 (Keputusan Investasi) yang diproksikan menggunakan PER (Price Earning RatioI) dengan jumlah data (N) sebanyak 18 dengan periode 2016-2019 memiliki nilai rata-rata tahun 2016, 2017, 2018 dan 2019 sebesar 14,52, 19,15, 20,88 dan 18,63. Untuk nilai terendah dari PER pada tahun 2016 yaitu 0,01, 2017 sebesar 0,56, di tahun 2018 sebesar 0,58 kemudian tahun 2019 sebesar 0,01. Nilai terendah dari PER pada tahun 2016-2019 dimiliki oleh perusahaan Ultra Jaya Milk Industry \& Tra (ULTJ), untuk tahun 2017 dan 2018 dimiliki oleh perusahaan Mandom Indonesia Tbk (TCID) dan untuk tahun 2019 dimiliki oleh perusahaan Indofood Sukses Makmur Tbk (INDF). Sedangkan nilai tertinggi PER untuk tahun 2016 sebesar 48,47, pada tahun 2017 sebesar 46,91, pada tahun 2018 sebesar 44,41 dan tahun 2019 sebesar 58,59. Nilai tertinggi PER untuk tahun 2016 dan 2017 dimiliki oleh perusahaan Tunas Baru Lampung Tbk (TBLA), untuk tahun 2018 dimiliki oleh perusahaan H.M Sampoerna Tbk (HMSP) dan untuk tahun 2019 termiliki oleh perusahaan Kimia Farma (Persero) Tbk (KAEF).

Pada varibel X2 (Keputusan Pendanaan) yang diproksikan tergunakannya DAR (Debt to Assets Ratio) dengan jumlah data (N) sebanyak 18 dengan periode 2016-2019 memiliki nilai rata-rata tahun 2016 sebesar 0,35, pada tahun 2017 sebesar 0,35, untuk tahun 2018 sebesar 0,33 dan tahun 2019 sebesar 0,43. Untuk nilai terendah DAR pada tahun 2016 sebesar 0,08, pada tahun 2017 sebesar 0,06, pada tahun 2018 sebesar 0,13 dan pada tahun 2019 sebesar 0,04. Nilai terendah DAR tahun 2016 dan 2018 dimiliki oleh Industri Jamu dan Farmasi Sido (SIDO), nilai terendah DAR tahun 2017 dimiliki oleh perusahaan Kimia Farma (Persero) Tbk (KAEF) dan nilai terendah DAR tahun 2019 dimiliki oleh perusahaan Kino Indonesia Tbk (KINO). Sedangkan untuk nilai tertingginya DAR tahun 2016 sebesar 0,72, pada tahun 2017 sebesar 0,78, pada tahun 2018 sebesar 0,71 dan pada tahun 2019 sebesar 0,79. Nilai tertinggi DAR untuk tahun 2016 dan 2018 dimiliki oleh perusahaan Tunas Baru Lamapung Tbk (TBLA), untuk tahun 2017 dimiliki oleh perusahaan Nippon Indosari Corpindo Tbk (ROTI) dan untuk tahun 2019 dimiliki oleh perusahaan Tunas Baru Lampung Tbk (TBLA).

Pada variabel X3 (Kebijakan Deviden) yang diproksikan menggunakan DPR (Dividend Payout Ratio) dengan jumlah data (N) sebanyak 18 dengan periode 2016-2019 memiliki nilai rata-rata tahun 2016 sebesar 0,55, pada tahun 2017 sebesar 0,59, tahun 2018 sebesar 0,73 dan tahun 2019 sebesar 1,04. Untuk nilai terendah DPR tahun 2016 sebesar 0,04, pada tahun 2017 sebesar 0,04, pada tahun 2018 sebesar 0,05 dan tahun 2019 sebesar 0,01. Nilai terendah dari DPR untuk tahun 2016 dimiliki oleh 
Indofood Sukses Makmur Tbk (INDF), untuk nilai terendah DPR tahun 2017 dan 2018 dimiliki oleh perusahaan Tempo Scan Pasific Tbk (TSPC) dan untuk nilai terendah DPR tahun 2019 dimiliki oleh perusahaan Kalbe Farma Tbk (KLBF). Sedangkan untuk nilai tertinggi DPR tahun 2016 sebesar 2,68, pada tahun 2017 sebesar 2,51, pada tahun 2018 sebesar 2,64 dan tahun 2019 sebesar 2,95. Nilai tertinggi DPR untuk tahun 2016, 2017 dan 2018 dimiliki oleh perusahaan Tunas Baru Lampung Tbk (TBLA). Sedangkan nilai tertinggi DPR untuk tahun 2019 dimiliki oleh perusahaan Ultra Jaya Milk Industry \& Tra (ULTJ).

Pada variabel Z (Ukuran Perusahaan) yang diproksikan menggunakan Size dengan jumlah data (N) sebanyak 18 dengan periode 2016-2019 memiliki rata-rata ditahun 2016 sebesar 13,78, pada tahun 2017 sebesar 14,73, pada tahun 2018 sebesar 14,37 dan pada tahun 2019 sebesar 15,59. Nilai terendah Size tahun 2016 sebesar 7,98, pada tahun 2017 sebesar 8,07, pada periode 2018 sebesar 8,10 dan periode 2019 sebesar 8,16. Nilai terendah dari ukuran perusahaan periode 2016 dimiliki oleh perusahaan Nippon Indosari Corpindo Tbk (ROTI) sedangkan nilai terendah ukuran perusahaan tahun 2017, 2018 dan 2019 dimiliki oleh perusahaan Chitose Internasional Tbk (CINT). Untuk nilai tertinggi tahun 2016 sebesar 21,15, pada periode 2017 sebesar 21,74, pada tahun 2018 sebesar 21,88 dan pada tahun 2019 sebesar 21,88. Nilai tertinggi ukuran perusahaan untuk tahun 2016 dimiliki oleh perusahaan Darya Varia Laboratoria Tbk (DVLA) sedangkan untuk tahun 2017, 2018 dan 2019 dipunyai emiten Multi Bintang Indonesia Tbk (MLBI).

Tabel 1

Hasil Pengujian Linier Berganda

\begin{tabular}{|l|c|c|}
\hline & B & Sig. \\
\hline Constant & $-2,185$ & 0,013 \\
\hline Keputusan Investasi (X1) & 0,032 & 0,031 \\
\hline Keputusan Pendanaan (X2) & 2,690 & 0,023 \\
\hline Kebijakan Deviden (X3) & 0,789 & 0,033 \\
\hline Ukuran Perusahaan (Z) & 0,287 & 0,000 \\
\hline
\end{tabular}

Sumber: Output SPSS 22 tahun 2020

Pada hasil persamaan regresi tersebut, dapat dilihat bahwa koefisien sebesar -2,185 menujukkan bahwa variabel Keputusan Investasi (X1), Keputusan Pendanaan (X2), Kebijakan Deviden (X3) dan Ukuran Perusahaan (Z) sama dengan 0, maka Nilai Perusahaan (Y) sebesar -2,185.

Koefisien regresi (beta $=\beta$ ) atas variabel keputusan investasi (X1) positif 0,032 . Hal tersebut menunjukkan bahwa variabel keputusan investasi keterkaitan positif dengan nilai perusahaan. Artinya jika nilai variabel keputusan investasi naik 1 satuan, maka nilai variabel nilai perusahaan akan mengalami kenaikan sebesar 0,032 dan sebaliknya.

Koefisien regresi (beta $=\beta$ ) atas variabel keputusan pendanaan (X2) bertanda positif 2,690. Hal tersebut menunjukkan bahwa variabel keputusan pendanaan berhubungan positif dengan nilai perusahaan. Artinya jika variabel keputusan pendanaan naik 1 satuan, maka nilai variabel nilai perusahaan akan mengalami kenaikan sebesar 2,690 dan sebaliknya.

Koefisien regresi (beta $=\beta$ ) atas variabel kebijakan deviden $(\mathrm{X} 3)$ bertanda positif 0,789 . Hal 
tersebut menunjukkan bahwa variabel kebijakan deviden berkaitan positif dengan nilai perusahaan. Artinya jika variabel kebijakan deviden dinaikkan 1 satuan, maka nilai variabel nilai perusahaan akan mengalami kenaikan sebesar 0,789 dan sebaliknya.

Koefisien regresi $($ beta $=\beta$ ) atas variabel ukuran perusahaan $(Z)$ bertanda positif 0,287 . Hal tersebut menunjukkan jika variabel ukuran perusahaan keterkitan positif dengan nilai perusahaan. Bermakna apabila variabel ukuran perusahaan naik 1 satuan, bermakna nilai variabel nilai perusahaan akan mengalami kenaikan sebesar 0,287 dan sebaliknya

Uji Koefisien determinasi diperolehnya nilai Adjusted $R$ Square sebesar 0,542 atau 54,2\%. Hasil output ini dapat diartikan bahwa 54,2\% variabel Nilai Perusahaan (Y) dipengaruhi oleh variabel Keputusan Investasi (X1), Keputusan Pendanaan (X2), Kebijakan Deviden (X3), Ukuran Perusahaan (Z). Sedangkan selebihnya 45,8\% terpengaruhi oleh indikator lain.

\section{B. Pembahasan}

Berdasarkan analisis regresi secara parsial, variabel putusan investasi memengaruhi nilai perusahaan yang mengindikasikan bahwa keputusan investasi yang dilakukan emiten dapat memberikan keuntungan dengan digunakan sumber daya yang dimiliki oleh emiten secara efisien, maka calon investor dengan mudah percaya kepada emiten untuk pembelian saham emiten tersebut yang nantinya bisa menaikkan harga saham dan meningkatkan nilai perusahaan. Makin baik putusan investasi yang yang terambil oleh manajemen keuangan perusahaan maka nilai perusahaan yang dihasilkan juga akan bertambah.

Secara parsial, variabel keputusan pendanaan memengaruhi nilai perusahaan. Hal tersebut karena perusahaan dalam penggunaan hutang pada operasionalnya akan didapatkan pengurangan pajak, dikarenakan hitungan pajak dari laba operasional setelah pengurangan dengan bunga utang jadi laba bersih yang dijadikan hak investor makin lebih besar. Faktor ini didukung oleh trade off theory yang meyebutkan bahwa untuk menaikkan nilai perusahaan pada keadaan tertentu perusahaan dapat meningkatkan nilai perusahaan karena dapat mengurangi penghasilan kena pajak.

Secara individual, variabel kebijakan deviden memengaruhi nilai perusahaan. Investor lebih menyukai keuntungan dibagikan sebagai deviden. Hal tersebut sama dengan teori bird in the hand yang menjelaskan pemegang saham menginginkan deviden yang tinggi dibandingkan capital gain terkait contohnya yakni pengembalian atas investasi yang sudah keluar. Jika deviden yang dibagikan perusahaan tinggi maka akan dapat menaikkan nilai perusahaan.

Tabel 2 Hasil Analisis Moderated Regression Analysis (MRA)

Keputusan Investasi (X1), Ukuran Perusahan (Z), Nilai Perusahaan (Y)

\begin{tabular}{|l|c|c|}
\hline & Koefisien Regresi & Sig. \\
\hline nstant & 0,511 & 0,669 \\
\hline & $-0,059$ & 0,278 \\
\hline & 0,176 & 0,040 \\
\hline${ }^{\prime} Z$ & 0,007 & 0,035 \\
\hline
\end{tabular}

Hasil analisis secara moderasi, variabel ukuran perusahaan mampu memperkuat pengaruhnya keputusan investasi pada nilai perusahaan. Jika emiten yang mampu membuat keputusan investasi 
dengan tepat maka mampu memengaruhi investor ketika ingin melakukan investasi. Selain itu perusahaan yang besar lebih banyak memiliki kesempatan investasi karena perusahaa yang besar memiliki keunggulan bersaing seperti kemudahan pada akses pasar, kemudahan untuk mendapatkan pendanaan eksternal dan kemudahan untuk berinvestasi.

Tabel 3 Hasil Analisis Moderated Regression Analysis (MRA) Keputusan Pendanaan (X2), Ukuran Perusahan (Z), Nilai Perusahaan (Y)

\begin{tabular}{|l|c|c|}
\hline & Koefisien Regresi & Sig. \\
\hline Constant & $-4,358$ & 0,048 \\
\hline X2 & 7,948 & 0,079 \\
\hline Z & 0,472 & 0,002 \\
\hline X2.Z & $-0,240$ & 0,422 \\
\hline
\end{tabular}

Secara moderasi, variabel ukuran perusahaan tidak mampu diperkuat pengaruhnya keputusan pendanaan pada nilai perusahaan. Emiten yang mempunyai aset yang besar atau kecil kurang begitu dilihat oleh pihak eksternal, karena investor menilai manajemen mengelola dana tesebut dengan efektif dan efisien agar tercapainya nilai positif bagi emiten.

Tabel 4 Hasil Analisis Moderated Regression Analysis (MRA) Kebijakan Deviden (X3), Ukuran Perusahan (Z), Nilai Perusahaan (Y)

\begin{tabular}{|l|c|c|}
\hline & Koefisien Regresi & Sig. \\
\hline Constant & $-1,096$ & 0,376 \\
\hline X3 & 1,075 & 0,358 \\
\hline Z & 0,286 & 0,001 \\
\hline X3.Z & 0,024 & 0,735 \\
\hline
\end{tabular}

Adanya ukuran perusahaan juga belum memperkuat pengaruhnya bijakan deviden pada nilai emiten. Hal ini karena besar atau kecilnya emiten belum memengaruhi jumlah deviden yang dibayarkan perusahaan. perusahaan yang besar bisa saja tidak membagikan deviden begitu juga sebaliknya perusahaan yang kecil bisa saja membagikan deviden. Besar kecilnya pembagian deviden ditentukan oleh perusahaan itu sendiri apakah akan menaikkan, menurunkan atau bahkan tidak membagikan deviden. Hal ini merupakan strategi perusahaan untuk mengelola keuntungan yang diperoleh untuk dialokasikan menjadi investasi, biaya operasional, membeli aset atau diberikan kepada pemegang saham sebagai deviden. Strategi lainnya yaitu pada perusahaan yang baru saja berdiri dengan total aset yang kecil tetapi mampu membayarkan deviden yang besar kepada investor. 


\section{SIMPULAN DAN SARAN}

\section{A. Kesimpulan}

Sesuai pengujian parsial keputusan investasi memengaruhi nilai perusahaan. Dikarenakan manajemen bisa mengelola putusan investasi yang memberikan keuntungan pada perusahaan sehingga investor memberikan kepercayaan dengan membeli saham perusahaan. Secara parsial keputusan pendanaan memengaruhi nilai perusahaan. dikarenakan pada keadaaan tertentu emiten akan meningkatkan penggunaan hutangnya sampai titik optimal untuk meningkatkan nilai perusahaannya karena dengan menggunakan hutang sehingga berkurangnya penghasilan kena pajak yang diberikan pemanfaatan bagi investor sehingga bisa menambah nilai emiten. Secara individual kebijakan deviden memengaruhi nilai perusahaan. Hasil tersebut menunjukkan bahwa investor menyukai keuntungan dibagikan sebagai deviden dibandingkan dengan capital gain. Makin tinggi terbaginya deviden maka nilai perusahaan akan ikut naik. Berdasarkan pengujian secara moderasi, ukuran perusahaan mampu memperkuat pengaruh keputusan investasi pada nilai perusahaan dikarenakan emiten yang bisa membuat putusan investasi dengan baik akan mampu memengaruhi kepercayaan investor untuk melakukan investasi. Selain itu perusahaan yang besar lebih banyak memiliki kesempatan investasi karena perusahaan yang besar memiliki keunggulan bersaing seperti kemudahan pada akses pasar, kemudahan untuk mendapatkan pendanaan eksternal dan kemudahan untuk berinvestasi. Pengujian secara moderasi menunjukkan hasil bahwa ukuran perusahaan belum memperkuat pengaruh putusan pendanaan pada nilai perusahaan. Hal tersebut karena besar kecilnya emiten tidak menjadi perhatian khusus, karena investor menilai pihak manajemen bagimana menggunakan dan mengelola pendanaan yang digunakan dengan efektif dan efisien guna pemaksimalan nilai perusahaan.Sesuai uji secara moderasi ditunjukkan ukuran perusahaan tidak mampu memperkuat pengaruh kebijakan deviden pada nilai perusahaan. Hal ini karena besar kecilnya emiten tidak memengaruhi jumlah deviden yang dibayarkan perusahaan. Jumlah deviden yang dibagikan tergantung dari kebijakan perusahaan itu sendiri mau menaikkan, menurunkan atau tidak membagikan sama sekali.

\section{B. Saran}

Sesuai hasil dipenelitian yang sudah dilakukan, maka dapat disampaikan saran-saran pada pihak tertentu yang memerlukan, yaitu yang pertama untuk investor yang akan melakukan investasi dengan tujuan untuk mendapatkan keuntungan maka investor perlu memerhatikan situasi emiten yang dapat terpilih atas indikator dalam maupun faktor luar emiten.

Bagi perusahaan disarankan untuk dapat pemaksiamalan nilai perusahaan jadi bisa menarik keminatan investor dalam penanaman modal pada perusahaan dilakukan penambahan terlaksanakannya fungsi dari manajemen keuangan dengan tepat, dikarenakan satu putusan manajemen yang terambil akan mempunyai pengaruh keputusan lainnya serta mempunyai dampak pada nilai emiten.

Bagi peneliti selanjutnya disarankan dalam penggunaan ataupun penambahan variabel lainnya yang memengaruhi nilai perusahaan seperti CSR, GCG, serta profitabilitas dikarenakan emiten dapat menciptakan nilai dengan pembangunan, kepercayaan pihak eksternal agar menarik investor dalam penentuan investasi untuk emiten dengan adanya profitabilitas yang tinggi memungkinkan emiten menggunakannya untuk pelaksanaan kegiatan CSR serta GCG. 
Fifta Dian Fitiriawati, Analisis Pengaruh Keputusan Investasi, Keputusan Pendanaan Dan Kebijakan Deviden Terhadap Nilai Perusahaan Dengan Ukuran Perusahaan Sebagai Variabel Moderasi

\section{Daftar Pustaka}

Animah dan Sri, R. 2010. Pengaruh Struktur Kepemilikan, Mekanisme GCG dan Ukuran Perusahaan pada Nilai Perusahaan Survei Pada Perusahaan Manufaktur Yang Terdaftar Di Bursa Efek Jakarta 2003-2007. Tesis Universitas Hasanudin Makasar.

Brigham dan Houston. 2010. Dasar-Dasar Manajemen Keuangan. Buku 1 Edisi 11. Jakarta: Salemba Empat.

Brigham dan Houston. 2014. Dasar-Dasar Manajemen Keuangan. Jakarta: Salemba Empat.

Fauziah, Anjiz dan Nadia Asandimitra. 2018. Pengaruh Keputusan Investasi, Keputusan Pendanaan, Kebijakan Dividend an Profitabilitas pada Nilai Perusahaan Studi Pada Perusahaan Industri Dasar dan Kimia Yang Terdaftar Di BEI Periode Tahun 2012-2016. Jurnal Manajemen Fakultas Ekonomi Universitas Negeri Surabaya.

Harmono. 2011. Manajemen Keuangan: Metode Balance Scorecard. Edisi 1. Cetakan 2. Jakarta: Bumi Aksara.

Harmono. 2014. Manajemen Keuangan Metode Balanced Scorecard. (Pendekatan Teori, Kasus, dan Riset Bisnis). Jakarta: Bumi Aksara.

Hilal, Suhaila. 2014. Pengaruh Keputusan Investasi, Keputusan Pendanaan, Kebijakan Dividen Dan Tingkat Suku Bunga Terhadap Nilai Perusahaan. Jurnal Ilmiah Manajemen dan Akuntansi Fakultas Ekonomi Universitas Pakuan

Mardiyati, Umi., Gatot Nazir Ahmad dan Muhammad Abrar. 2015. Pengaruh Keputusan Investasi, Keputusan Pendanaan, Ukuran Perusahaan dan Profitabilitas Terhadap Nilai Perusahaan Pada Sektor Manufaktur Barang Konsumsi Yang Terdaftar Di BEI Tahun 2010-2013. Jurnal Riset Manajemen Fakultas Ekonomi Universitas Negeri Jakarta.

Piristina, Deny Alvita dan Khairunnisa. 2019. Analisis Pengaruh Kebijakan Deviden, Keputusan Investasi Dan Keputusan Pendanaan Terhadap Nilai Perusahaan. Jurnal Akuntansi Fakultas Ekonomika dan Bisnis Universitas Telkom Bandung.

Sofia, Dewi Martha dan Farida, N. 2017. Pengaruh Kebijakan Hutang, Kebijakan Deviden serta Keputusan Investasi Pada Nilai Perusahaan Pada Sub Sektor Perdagangan Besar Yang Terdaftar Di Bursa Efek Indonesia Periode 2010-2014. Jurnal Ilmu Administrasi Bisnis Fakultas Ilmu Sosial dan Ilm Politik Universitas Riau.

Sudana, I Made. 2011. Manajemen Keuangan Perusahaan: Teori dan Praktik. Edisi 2. Jakarta: Penerbit Erlangga.

Utami, A dan Ayu, Ni Putu. 2018. Pengaruh Keputusan Pendanaan, Keputusan investasi serta Kebijakan Deviden Terhadap Nilai Perusahaan Food And Beverage. E-Jurnal Manajemen Fakultas Ekonomi dan Bisnis Universitas Udayana Bali.

www.cnbcindonesia.com 